\title{
Treatment Literacy of People Living with HIV (PLHIV) in Government Healthcare Facilities in Malaysia
}

\author{
Zailatul Hani Mohamad Yadzir ${ }^{1}$, Mazliza Ramly², Anita Suleiman ${ }^{3}$ \\ ${ }^{1,2,3}$ HIV/STI/Hep C Sector, Disease Control Division, Ministry of Health Malaysia, Federal Government \\ Administrative Centre, 62590 Putrajaya, Malaysia
}

Corresponding Author: Zailatul Hani Mohamad Yadzir

\begin{abstract}
Background: Treatment literacy is a significant factor in the management of health and care of people living with HIV (PLHIV). Therefore, the aim of this study was to determine the level of treatment literacy among PLHIV in selected government facilities.

Methods: A cross-sectional study was undertaken from July to August 2020 in five government hospitals and six government health clinics in Malaysia. A validated self-administered questionnaire encompassing six items about treatment literacy was used to assess the knowledge of PLHIV. This survey was conducted via web-based platform.

Results: Overall, 1173 PLHIV participated in this study. The major finding in this study was that $90.0 \%$ of PLHIV were currently on treatment and aware of their antiretroviral therapy (ART) regime. Majority of PLHIV (74.0\%) also stated that they know the frequency of receiving their viral load test. Conclusion: The study found a high level of treatment literacy among PLHIV in selected government facilities in Malaysia.
\end{abstract}

Key words: Human immunodeficiency virus/acquired immunodeficiency syndrome (HIV/AIDS), people living with HIV (PLHIV), antiretroviral therapy (ART)

\section{INTRODUCTION}

The human immunodeficiency virus/ acquired immunodeficiency syndrome (HIV/AIDS) epidemic has slowed worldwide due at least in part to the development of potent ART. The number of HIV/AIDS-related death has decreased from 2.3 million in 2005 to 690,000 in $2019 .{ }^{(1)}$ Although treatment regimens for HIV/AIDS are becoming less complex with the advent of combined drugs in single medications and through twice-a-day and once-a-day dosing, treatment literacy will most likely remain an important barrier to life-long treatment adherence even for the simplest regimens. ${ }^{(2)}$ Studies in PLHIV have shown that low treatment literacy is associated with lower medication adherence which led to drug resistance, ultimately causing specific medication regimens to become ineffective, (3) poorer clinical outcomes including higher viral load (4) and more hospitalisations. ${ }^{(5)}$ In recent years, the Joint United Nations Programme on HIV/AIDS (UNAIDS) has firmly endorsed the HIV Undetectable $=$ Untransmittable or $\mathrm{U}=\mathrm{U}$ concept. ${ }^{(6)} \mathrm{U}=\mathrm{U}$ means that PLHIV who achieve and maintain undetectable viral load by taking ART daily as prescribed cannot sexually transmit the virus to their partner. Thus, treatment for HIV is a powerful arrow in the quiver of HIV prevention tools. So far, little is known about treatment literacy among PLHIV in Malaysia. Therefore, the objective of this study was to determine the level of treatment literacy among PLHIV in 
Zailatul Hani Mohamad Yadzir et.al. Treatment literacy of people living with HIV (PLHIV) in government healthcare facilities in Malaysia.

selected government facilities.

\begin{tabular}{|c|c|c|c|c|c|c|c|c|c|c|c|c|c|c|}
\hline & \multirow{2}{*}{ Item } & & \multicolumn{2}{|c|}{ Yes } & \multicolumn{2}{|c|}{ No } & & & & & & & & \\
\hline & & & $\mathrm{n}$ & $(\%)$ & $\mathrm{n}$ & $(\%)$ & & & & & & & & \\
\hline \multirow[t]{3}{*}{1} & $\begin{array}{l}\text { Are you currently on } \\
\text { antiretroviral therapy } \\
\text { (ART)? }\end{array}$ & $(\mathrm{N}=1173)$ & 1055 & $(90.0)$ & 118 & (10.0) & & & & & & & & \\
\hline & \multirow[t]{2}{*}{ Item } & & \multicolumn{2}{|c|}{$\begin{array}{l}\text { First-line } \\
\text { regimen }\end{array}$} & \multicolumn{2}{|c|}{$\begin{array}{l}\text { Second-line } \\
\text { regimen }\end{array}$} & \multicolumn{2}{|c|}{ Not sure } & & & & & & \\
\hline & & & $\mathrm{n}$ & $(\%)$ & $\mathrm{n}$ & $(\%)$ & $\mathrm{n}$ & $(\%)$ & & & & & & \\
\hline \multirow[t]{3}{*}{2} & $\begin{array}{l}\text { Are you currently on a } \\
\text { first-line or second-line } \\
\text { ART regimen? }\end{array}$ & $(\mathrm{N}=1055)^{*}$ & 738 & (69.9) & 86 & (8.2) & 231 & (21.9) & & & & & & \\
\hline & \multirow{2}{*}{ Item } & & \multicolumn{2}{|c|}{ Yes } & \multicolumn{2}{|c|}{ No } & & & & & & & & \\
\hline & & & $\mathrm{n}$ & $(\%)$ & $\mathrm{n}$ & $(\%)$ & & & & & & & & \\
\hline \multirow[t]{3}{*}{3} & $\begin{array}{l}\text { In the last } 6 \text { months, } \\
\text { have you received a } \\
\text { viral load test? }\end{array}$ & $(\mathrm{N}=1173)$ & 986 & $(84.1)$ & 187 & (15.9) & & & & & & & & \\
\hline & \multirow{2}{*}{ Item } & & \multicolumn{2}{|c|}{ Yes } & \multicolumn{2}{|c|}{ No } & \multicolumn{2}{|c|}{ Not sure } & & & & & & \\
\hline & & & $\mathrm{n}$ & $(\%)$ & $\mathrm{n}$ & $(\%)$ & $\mathrm{n}$ & $(\%)$ & & & & & & \\
\hline \multirow[t]{3}{*}{4} & $\begin{array}{l}\text { Was your viral load } \\
\text { suppressed at your last } \\
\text { viral load test? }\end{array}$ & $(\mathrm{N}=986)^{\phi}$ & 713 & (72.3) & 148 & (15.0) & 125 & (12.7) & & & & & & \\
\hline & \multirow{2}{*}{ Item } & & \multicolumn{2}{|c|}{ Yes } & \multicolumn{2}{|c|}{ No } & \multicolumn{2}{|c|}{ Not sure } & & & & & & \\
\hline & & & $\mathrm{n}$ & $(\%)$ & $\mathrm{n}$ & $(\%)$ & $\mathrm{n}$ & $(\%)$ & & & & & & \\
\hline \multirow[t]{3}{*}{5} & $\begin{array}{l}\text { Do you know how } \\
\text { often you should } \\
\text { receive a viral load } \\
\text { test? }\end{array}$ & $(\mathrm{N}=1173)$ & 868 & $(74.0)$ & 138 & (11.8) & 167 & (14.2) & & & & & & \\
\hline & \multirow[t]{2}{*}{ Item } & & \multicolumn{2}{|c|}{ Every month } & \multicolumn{2}{|c|}{$\begin{array}{l}\text { Every } 3 \\
\text { months }\end{array}$} & \multicolumn{2}{|c|}{$\begin{array}{l}\text { Every } 6 \\
\text { months }\end{array}$} & \multicolumn{2}{|c|}{ Every year } & \multicolumn{2}{|c|}{$\begin{array}{c}\text { Every } 2 \\
\text { years }\end{array}$} & & ired \\
\hline & & & $\mathrm{n}$ & $(\%)$ & $\mathrm{n}$ & $(\%)$ & $\mathrm{n}$ & $(\%)$ & $\mathrm{n}$ & $(\%)$ & $\mathrm{n}$ & $(\%)$ & $\mathrm{n}$ & $(\%)$ \\
\hline 6 & $\begin{array}{l}\text { How often should you } \\
\text { receive a viral load } \\
\text { test? }\end{array}$ & $(\mathrm{N}=868)^{\ddagger}$ & 19 & $(2.2)$ & 53 & (6.1) & 620 & (71.4) & 175 & (20.2) & 0 & 0 & 1 & (0.1) \\
\hline
\end{tabular}

*Total number of PLHIV who answered Yes in Item 1

${ }^{\phi}$ Total number of PLHIV who answered Yes in Item 3

¥Total number of PLHIV who answered Yes in Item 5

This study was a cross-sectional study using a validated self-administered questionnaire survey which was conducted from July to August 2020 via online. Five government hospitals and six government health clinics were selected from six states; Penang, Selangor, Kuala Lumpur, Johor, Melaka and Pahang. The six states were selected as $70.0 \%$ of the 2019 reported new HIV cases were contributed from these states. ${ }^{(7)}$ All the eleven selected study sites provided HIV/AIDS care and services to the public. The study subject was a PLHIV who receiving care and services in the selected study sites and met the inclusion criteria. The inclusion criteria included; age 18 years and above, registered as patient in the selected study sites, living with HIV, able to understand Malay or English language and willing to provide informed consent. No personal information was asked to maintain anonymity. For the recruitment, PLHIV were approached by clinic staff or case worker during their scheduled appointments. Those interested in participating were given a recruitment message with a hyperlink or QR code to the online survey website. The questionnaire encompassing six items about treatment literacy was used to assess the knowledge of PLHIV. Sample size was calculated to be 1771 assuming $95.0 \%$ confidence level with $5.0 \%$ margin error and $50.0 \%$ response rate. The study received ethical approval from the Medical Research and Ethics Committee, Ministry of Health Malaysia and this study was registered under Malaysia National Medical Research 
Registry (NMRR) with the identification number NMRR-20-1932-55728. Statistical analysis was done using the Statistical Package for Social Sciences (SPSS 26.0) software.

The response rate for the study sample was $66.2 \%$. In total, 1173 PLHIV participated in this study. Of the 1173 PLHIV, $767(65.0 \%)$ receiving care and services in hospitals and $406(35.0 \%)$ in health clinics. The major finding in this study was that $90.0 \%$ of PLHIV were currently on treatment and aware of their ART regime (Table 1). Almost seventy percent $(69.9 \%)$ of them stated that they were currently on the first-line ART regime. Only $8.2 \%$ of them were on the second-line ART regime which may be associated with poor adherence which led to drug resistance or due to severe side effects causing the first-line ART regime to become ineffective. Majority of PLHIV (74.0\%) also reported that they know the frequency of receiving their viral load test. Seventy one percent $(71.4 \%)$ of them stated that they should receive a viral load test every 6 months. This is consistent with the current practice in Malaysia where HIV viral load is monitored every 6 months. ${ }^{(8)}$ This finding highlights that majority of PLHIV have a high level of treatment literacy which associated with higher medication adherence and good clinical outcomes which lower viral loads. Nevertheless, viral load test results are needed in order to confirm this finding. In conclusion, the study found a high level of treatment literacy among PLHIV in selected government facilities in Malaysia.

\section{ACKNOWLEDGEMENTS}

The authors thank the Director General of Health Malaysia for his permission to publish this paper. The authors also thank all the respondents who participated in the study.

\section{Conflict of Interest: None}

Source of Funding: None
Ethical Approval: The study received ethical approval from the Medical Research and Ethics Committee, Ministry of Health Malaysia and this study was registered under Malaysia National Medical Research Registry (NMRR) with the identification number NMRR-20-1932-55728.

\section{REFERENCES}

1. The Joint United Nations Programme on HIV/AIDS (UNAIDS) (2020) 2020 Global Fact Sheet. Available from https://www.unaids.org/sites/default/file s/media_asset/UNAIDS_FactSheet_en.p df [Cited: 4 May 2021]

2. Kalichman SC, Ramachandran B, Catz $\mathrm{S}$. Adherence to combination antiretroviral therapies in HIV patients of low health literacy. J Gen Intern Med. 1999; 14(5): 267-73

3. Pellowski JA, Kalichman SC. Health behavior predictors of medication adherence among low health literacy people living with HIV/AIDS. J Health Psychol. 2016; 21(9): 1981-91

4. Kalichman SC, Rompa D. Functional health literacy is associated with health status and health-related knowledge in people living with HIV-AIDS. J Acquir Immune Defic Syndr. 2000; 25(4): 33744

5. Palumbo R. Discussing the effects of poor health literacy on patients facing HIV: A narrative literature review. Int Journal Health Policy Manag. 2015; 4(7): 417-30

6. Joint United Nations Programme on HIV/AIDS (UNAIDS) (2018) Available from

https://www.unaids.org/en/resources/pre sscentre/featurestories/2018/july/undetec table-untransmittable [Cited: 20 April 2021]

7. Malaysia Global AIDS Monitoring (2020) Available from https://www.moh.gov.my/moh/resources /Penerbitan/Laporan/Umum/Laporan_Gl obal_AIDS_Monitoring_2020_new.pdf [Cited: 27 May 2021] 
Zailatul Hani Mohamad Yadzir et.al. Treatment literacy of people living with HIV (PLHIV) in government healthcare facilities in Malaysia.

8. Guidelines for the Management of Adult HIV Infection with Antiretroviral Therapy (2011) Available from https://www.moh.gov.my/moh/resources /auto\%20download\%20images/589d71c 4dd799.pdf [Cited: 25 May 2021]
How to cite this article: Yadzir ZHM, Ramly M, Suleiman A. Treatment literacy of people living with HIV (PLHIV) in government healthcare facilities in Malaysia. Int J Health Sci Res. 2021; 11(9): 79-82. DOI: https://doi.org/10.52403/ijhsr. 20210912 